\title{
ANALISIS PERHITUNGAN DAN PELAPORAN PAJAK ATAS PENEBUSAN LPG 3KG DARI PERTAMINA PADA PT. BERKAT JABES
}

\author{
Vrenshit Merdekhawati Corneles \\ Ventje Ilat \\ Victorina Z. Tirayoh \\ Fakultas Ekonomi dan Bisnis Jurusan Akuntansi \\ Universitas Sam Ratulangi Manado \\ E-mail : cvrenshit@yahoo.co.id
}

\begin{abstract}
ABSTRAK
Program pemerintah untuk peralihan Bahan Bakar Minyak ke Bahan Bakar Gas sejak tahun 2007 membuat PT. Berkat Jabes yang tadinya merupakan agen minyak tanah, ikut beralih menjadi agen penyalur BBG, khususnya LPG 3Kg. Terhitung sejak Mei 2012. Untuk setiap pembelian/penebusan LPG 3kg PT. Berkat Jabes harus membayar PPh Pasal 22 dengan tarif 0,3\% serta PPN sebesar 10\% atas penjualan. Tujuan penelitian ini adalah untuk mengetahui dan menganalisis perhitungan dan pelaporan pajak atas pembelian/penebusan LPG $3 \mathrm{~kg}$, yaitu PPh Pasal 22 dan PPN apakah sudah sesuai dengan ketentuan perpajakan yang berlaku. Metode yang digunakan dalam penelitian ini adalah kuantitatif deskriptif, data-data kuantitatif yang diperoleh penulis kemudian diolah dan dianalisis untuk menjelaskan bagaimana proses perhitungan dan pelaporan pajak yang dilakukan PT. Berkat Jabes. Dari hasil penelitian, menunjukan bahwa PT. Berkat Jabes telah melaksanakan kewajiban perpajakannya dengan baik, namun masih perlu melengkapi dokumen-dokumen perpajakan atas pembayaran PPh 22 dan PPN serta melakukan pencatatan akuntansi sesuai transaksi pembelian/penebusan yang terjadi.
\end{abstract}

Kata Kunci : Perhitungan, pelaporan, PPh Pasal 22, PPN, pembelian/penebusan LPG 3kg

\begin{abstract}
Government program over the transition from oil fuel to gas fuel since 2007 has made PT. Berkat Jabes that had worked as kerosene dealer, turned to join as LPG dealer, especially $3 \mathrm{~kg} L P G$ as from May 2012. For each purchase/redemption of $3 \mathrm{~kg}$ LPG PT. Berkat Jabes have to pay Income Tax article 22 at the rate of 0,3\% and $10 \%$ VAT. The objective of this study is to analyze the calculation and reporting tax of the purchased of $3 \mathrm{~kg}$ $L P G$ if it is in accordance with the provisions of the applicable tax. The method that has been used in this research is descriptive quantitative. Quantitatve data that obtained by the author was processed and analyzed to describe the process of calculating and reporting tax by PT. Berkat Jabes. The result from the research showed that PT. Berkat Jabes has fully run their tax obligation, but still need to complete the documents upon the payment of Income Tax article 22 and VAT and make the right accounting records based on the transactions of purchase/redemption that have occurred.
\end{abstract}

Keywords : Calculation, reporting, Income Tax Article 22, VAT, the purchase/redemption $3 \mathrm{~kg}$ LPG 


\section{PENDAHULUAN}

\section{Latar Belakang}

Salah satu penyumbang pendapatan negara terbesar adalah pajak dari industri minyak dan gas, khususnya dalam usaha pemasaran migas, pajak yang dipungut antara lain adalah Pajak Penghasilan Pasal 22 yang wajib dipungut oleh Pertamina dan badan usaha lainnya yang bergerak dalam bidang bahan bakar minyak jenis premix, super TT, minyak tanah, gas LPG dan pelumas serta PPN atas penjualan hasil produksinya. Objek dalam penelitian ini adalah agen resmi Pertamina, yaitu PT. Berkat Jabes.

PT. Berkat Jabes merupakan agen resmi Pertamina yang menjadi penyalur Bahan Bakar Minyak, yaitu minyak tanah. Namun sejak adanya program pemerintah untuk pengalihan Bahan Bakar Minyak ke Bahan Bakar Gas sejak tahun 2007 dengan pertimbangan bahwa dalam rangka untuk menjamin penyediaan dan pengadaan Bahan Bakar di dalam negeri dan mengurangi subsidi Bahan Bakar Minyak guna meringankan beban keuangan negara, perlu dilakukan substitusi penggunaan Minyak Tanah ke Liquefied Petroleum Gas maka ditetapkanlah Peraturan Presiden Nomor 104 tahun 2007 tentang Penyediaan, Pendistribusian, dan Penetapan Harga Liquefied Petroleum Gas Tabung 3 Kilogram.

Liquefied Petroleum Gas yang selanjutnya disebut LPG adalah gas hidrokarbon yang dicairkan dengan tekanan untuk memudahkan penyimpanan, pengangkutan, dan penanganannya yang pada dasarnya terdiri atas propana, butana, atau campuran keduanya. LPG Tabung 3 Kilogram yang selanjutnya disebut LPG Tabung 3 Kg adalah LPG yang diisikan ke dalam tabung dengan berat isi 3 Kilogram. Harga patokan untuk LPG 3 Kg ini adalah harga yang didasarkan pada harga indeks pasar LPG yang berlaku pada bulan yang bersangkutan ditambah biaya distribusi (termasuk handling) dan margin usaha yang wajar.

Terhitung sejak bulan Mei 2012 PT. Berkat Jabes mengkhususkan penyaluran produknya berupa Liquefied Petroleum Gas (LPG) 3 kilogram yang ditebus/dibeli dari PT. Pertamina. Atas pembelian tersebut, PT. Berkat Jabes harus membayar Pajak Penghasilan Pasal 22 dengan tarif untuk Gas LPG sebesar 0,3\%, bersifat final terhadap agen/penyalur dan PPN sebesar 10\% atas setiap penyerahan barang.

Berdasarkan latar belakang masalah tersebut, maka penulis tertarik melakukan penelitian dengan judul skripsi "Analisis Perhitungan dan Pelaporan Pajak atas Penebusan Lpg 3kg dari Pertamina pada Pt. Berkat Jabes Manado".

\section{Tujuan Penelitian}

Dengan dilakukannya penelitian ini, maka tujuan yang ingin dicapai adalah untuk mengetahui dan menganalisis perhitungan dan pelaporan pajak penghasilan pasal 22 dan PPN yang dipungut atas pembelian produk Pertamina berupa gas LPG 3Kg oleh PT.Berkat Jabes apakah sudah sesuai dengan ketentuan yang berlaku.

\section{Pertamina}

\section{TINJAUAN PUSTAKA}

Pertamina adalah perusahaan nasional yang berusaha dibidang pertambangan minyak dan gas bumi milik bangsa Indonesia yang dikuasai negara. Tujuan Pertamina termasuk membangun dan melaksanakan penguasaan migas dalam arti seluas-luasnya untuk sebesar-besarnya kemakmuran rakyat dan negara serta menciptakan ketahanan nasional (Muljono, 2007 :14).

Berdasarkan Peraturan Menteri Keuangan No. 224/PMK.011/2012, PT Pertamina merupakan BUMN yang ditunjuk atau diberi wewenang oleh pemerintah sebagai Pemungut pajak atau wajib pungut atas penjualan hasil produksinya.

\section{Pajak Pertambahan Nilai}

Pajak Pertambahan Nilai Barang dan Jasa serta Pajak Penjualan Atas Barang Mewah atau disingkat PPN dan PPNBM merupakan pajak yang dikenakan atas konsumsi di dalam negeri (di dalam Daerah Pabean), baik konsumsi barang maupun konsumsi jasa. Oleh karena itu barang yang tidak dikonsumsi di dalam Daerah Pabean (diekspor), dikenakan pajak dengan tarif 0\% (nol persen). Pajak Pertambahan Nilai dikenakan hanya terhadap pertambahan nilainya saja dan dipungut beberapa kali pada berbagai mata rantai jalur perusahaan.

Tarif Pajak Pertambahan Nilai sebesar 10\% (sepuluh persen). Tarif Pajak Pertambahan Nilai yang berlaku atas penyerahan BKP/JKP adalah tarif tunggal, sehingga mudah dalam pelaksanaannya dan tidak memerlukan daftar penggolongan barang atau penggolongan jasa dengan tarif yang berbeda sebagaimana berlaku pada Pajak Penjualan atas Barang Mewah (Muhamad : 2007).. 
Berdasarkan UU No. 42 Tahun 2009 Penyetoran dan pelaporan PPN dilakukan paling lama akhir bulan berikutnya setelah berakhirnya Masa Pajak dan sebelum SPT Masa PPN disampaikan (Psl 15A).

\section{Pajak Penghasilan Pasal 22}

Pajak Penghasilan (PPh) Pasal 22 merupakan pembayaran Pajak Penghasilan dalam tahun berjalan yang dipungut oleh bendaharawan pemerintah baik pusat maupun daerah, instansi atau lembaga pemerintah, dan lembaga-lembaga negara lainnya sehubungan dengan pembayaran atas penyerahan barang, atau badan-badan tertentu, baik badan pemerintah maupun swasta berkenaan dengan kegiatan di bidang impor atau kegiatan di bidan lain.

Tabel 1. Tarif PPh 22 Dipungut oleh Pertamina dan Badan Usaha Selain Pertamina JENIS USAHA

TARIF

\begin{tabular}{lll}
\hline Premium & & \\
& SPBU Swasta & $0,30 \%$ dari penjualan \\
Solar & SPBU Pertamina & $0,25 \%$ dari penjualan \\
& & \\
& SPBU Swasta & $0,30 \%$ dari penjualan \\
Premix & SPBU Pertamina & $0,25 \%$ dari penjualan \\
& SPBU Swasta & $0,30 \%$ dari penjualan \\
& SPBU Pertamina & $0,25 \%$ dari penjualan \\
Minyak tanah & $0,30 \%$ dari penjualan \\
Gas LPG & & $0,30 \%$ dari penjualan \\
Pelumas & & $0,30 \%$ dari penjualan
\end{tabular}

Penyetoran PPh Pasal 22 dilakukan secara kolektif dengan menggunakan formulir Surat Setoran Pajak. Pemungut pajak harus menyampaikan Surat Pemberitahuan Masa paling lambat 20 (dua puluh) hari setelah Masa Pajak berakhir.

Tabel 2. Penelitian Terdahulu

\begin{tabular}{|c|c|c|c|c|c|c|}
\hline $\begin{array}{l}\text { Nama } \\
\text { Peneliti/ta } \\
\text { hun }\end{array}$ & Judul & Tujuan & $\begin{array}{l}\text { Metode } \\
\text { Penelitian }\end{array}$ & Hasil Penelitian & Persamaan & Perbedaan \\
\hline $\begin{array}{l}\text { Kuswanto } \\
\text { (2011) }\end{array}$ & $\begin{array}{l}\text { Analisis Selisih } \\
\text { Perhitungan } \\
\text { Pajak } \\
\text { Penghasilan } \\
\text { Final Pasal } 22 \\
\text { Atas Penjualan } \\
\text { Bahan Bakar } \\
\text { Minyak } \\
\text { Terhadap } \\
\text { Laporan Pajak }\end{array}$ & $\begin{array}{l}\text { Untuk mengetahui apakah } \\
\text { perhitungan Pajak } \\
\text { Penghasilan final Pasal } 22 \\
\text { di SPBU 34.151.37 dan } \\
\text { Pertamina sebagai } \\
\text { pemungut telah sesuai } \\
\text { dengan perturan yang } \\
\text { berlaku }\end{array}$ & $\begin{array}{l}\text { Kuantitatif } \\
\text { Deskriptif }\end{array}$ & $\begin{array}{l}\text { PT Cita Lini } \\
\text { Persada selaku } \\
\text { pemilik SPBU } \\
\text { melaporkan pajak } \\
\text { penghasilan final } \\
\text { pasal } 22 \text { sesuai } \\
\text { jumlah pajak yang } \\
\text { dipungut meskipun } \\
\text { dalam } \\
\text { perhitungannya ada } \\
\text { selisih jumlah pajak. } \\
\text {. }\end{array}$ & $\begin{array}{l}\text { Meneliti } \\
\text { perhitunga } \\
\mathrm{n} \quad \text { dan } \\
\text { pelaporan } \\
\text { PPh Pasal } \\
22 \text { yang } \\
\text { dipungut } \\
\text { Pertamina. }\end{array}$ & $\begin{array}{l}\text { Objek } \\
\text { penelitian. } \\
\text { Penelitian } \\
\text { sebelumn } \\
\text { ya hanya } \\
\text { dilakukan } \\
\text { untuk } \\
\text { perhitunga } \\
\text { n dan } \\
\text { pelaporan } \\
\text { PPh 22 }\end{array}$ \\
\hline $\begin{array}{l}\text { Christant } \\
\text { y } \\
(2012)\end{array}$ & $\begin{array}{l}\text { ANALISIS } \\
\text { EKUALISASI } \\
\text { PAJAK } \\
\text { PENGHASILA } \\
\text { N PASAL } 22 \\
\text { DAN PAJAK } \\
\text { PERTAMBAH } \\
\text { AN NILAI DI } \\
\text { PT KAS }\end{array}$ & $\begin{array}{l}\text { Untuk menilai dan } \\
\text { mengevaluasi penyebab } \\
\text { terjadinya perbedaan antara } \\
\text { nilai total penjualan dalam } \\
\text { negeri yang dapat } \\
\text { dikenakan PPh Pasal } 22 \\
\text { dengan nilai total } \\
\text { penyerahan yang } \\
\text { dilaporkan dalam SPT PPN }\end{array}$ & $\begin{array}{l}\text { Kuantitatif } \\
\text { Deskriptif }\end{array}$ & $\begin{array}{l}\text { perusahaan telah } \\
\text { melakukan } \\
\text { perhitungan dengan } \\
\text { benar, ditunjukkan } \\
\text { dari kesamaan nilai } \\
\text { antara nilai PPh } \\
\text { Pasal } 22 \text { dan total } \\
\text { penyerahan yang } \\
\text { dilakukan } \\
\text { perusahaan. }\end{array}$ & $\begin{array}{l}\text { Meneliti } \\
\text { perhitunga } \\
\text { n PPh } \\
\text { pasal } 22 \\
\text { dan PPN }\end{array}$ & $\begin{array}{l}\text { Objek } \\
\text { penelitian. }\end{array}$ \\
\hline
\end{tabular}




\section{METODE PENELITIAN}

\section{Jenis Penelitian}

Jenis penelitian ini adalah deskriptif. Penelitian deskriptif merupakan penelitian terhadap masalahmasalah berupa fakta-fakta saat ini dari suatu populasi ( Indriantoro dan Supomo, 2012: 26).

\section{Tempat dan Waktu Penelitian}

Tempat penelitian dilaksanakan di PT. Berkat Jabes di Manado, dengan meminta data formulir setoran atas pembelian/penebusan LPG 3kg dari Pertamina. Namun karena kurang lengkapnya data pada PT Berkat Jabes maka penulis pun meminta data dari pihak Pertamina, yaitu di PT. Pertamina yang berlokasi di Bitung. Data tersebut berupa data bukti potong PPh pasal 22 dan faktur pajak PPN atas pembelian PT. Berkat Jabes berupa gas LPG $3 \mathrm{~kg}$ dari Pertamina selama tahun 2012. Waktu penelitian pada bulan November sampai Desember tahun 2013.

\section{Prosedur Penelitian}

Prosedur penelitian yang dilakukan penulis adalah sebagai berikut.

1. Permohonan mengadakan penelitian pada PT. Berkat Jabes, Manado dan PT. Pertamina di Bitung

2. Disposisi Pimpinan Instansi : Setelah pemasukan surat permohonan penelitian, Bidang Umum dan Kerjasama, menindak lanjuti pembuatan surat perintah yang menjelaskan tentang izin penelitian pada instansi tersebut dengan persetujuan pimpinan instansi.

3. Pengumpulan Data : Dalam tahap ini peneliti melaksanakan proses pengumpulan data yang akan dipakai dalam penelitian dan penyusunan skripsi, yaitu melaksanakan wawancara di bagian administrasi PT. Berkat Jabes, kemudian mengambil data berupa formulir setoran pembayaran atas pembelian/penebusan produk Pertamina dari perusahaan, kemudian melakukan wawancara di bagian keuangan PT Pertamina Bitung, dan meminta data berupa bukti potong PPh Pasal 22 atas PT. Berkat Jabes beserta faktur pajak PPN. Dalam tahap ini penulis melakukan analisis data yang telah dikumpulkan dan melakukan pembahasan tentang rumusan masalah dalam penelitian dan menentukan hasil penelitian.

4. Menarik Kesimpulan : Pada tahap ini peneliti menarik kesimpulan dari penelitian yang dilakukan sebagai akhir dari penelitian ini.

\section{Metode Pengumpulan Data}

\section{Jenis Data}

Data adalah sekumpulan fakta yang diperoleh melalui pengamatan (observasi) langsung atau survei (Indriantoro dan Supomo, 2012: 10). Dalam penelitian ini menggunakan dua jenis data yaitu:

a. Data Kuantitatif adalah data penelitian berupa angka-angka atau numerik dan analisis menggunakan statistik.

b. Data Kualitatif adalah data yang disajikan secara deskriptif dan tidak dapat diukur dengan skala numerik.

\section{Sumber Data}

1. Data Primer, merupakan sumber data penelitian yang diperoleh secara langsung dari sumber asli atau tidak melalui media perantara (Indriantoro dan Supomo, 2012: 146).

2. Data Sekunder, merupakan sumber data penelitian yang diperoleh peneliti secara tidak langsung melalui media perantara atau diperoleh dan dicatat oleh pihak lain (Indriantoro dan Supomo, 2012: 147).

\section{Teknik Pengumpulan Data}

Kualitas instrumen penelitian berkenaan dengan validitas dan reliabilitas instrumen dan kualitas pengumpulan data berkenaan ketepatan cara-cara yang digunakan untuk mengumpulkan data (Sugiyono 2012 :137).

1. Penelitian Lapangan (field research), merupakan kegiatan kunjungan serta kegiatan pengumpulan data ditempat atau objek yang memiliki sumber data yang sesuai dengan penelitian, dan data diperoleh melalui cara: 
a. Wawancara, adalah teknik pengumpulan data dengan cara mengadakan kegiatan komunikasi langsung dengan pihak-pihak instansi yang terkait, dan membahas masalah-masalah yang dikemukakan dalam penelitian ini.

b. Dokumenter, merupakan cara pengumpulan data dengan menggunakan arsip atau dokumendokumen yang bersifat tulisan dari instansi yang bersangkutan.

2. Penelitian Kepustakaan (library Research), merupakan cara pengumpulan yang dilakukan dengan mengumpulkan data dari teori-teori yang diperoleh dan dipelajari dari buku-buku, literatur, jurnal, serta bahan-bahan informasi lainnya yang berhungan dengan masalah yang diteliti untuk digunakan sebagai landasan pemikiran teoritis bagi penulis didalam membahas penelitian ini.

\section{Metode Analisis Data}

Metode yang digunakan adalah metode deskriptif yaitu metode dengan mengumpulkan data, menyusun selanjutnya dianalisis dengan mengolah kembali data yang diperoleh.

\section{HASIL PENELITIAN DAN PEMBAHASAN}

\section{Gambaran Umum Objek Penelitian}

\section{Profil PT Berkat Jabes Manado}

PT Berkat Jabes berlokasi di Desa Picuan Baru, Kecamatan Motoling Kabupaten Minahasa Selatan. PT Berkat Jabes sebelumnya bernam UD. Sandra merupakan agen/penyalur Bahan Bakar Minyak, khususnya minyak tanah. Namun sejak adanya program pemerintah untuk peralihan Bahan Bakar Minyak ke Bahan Bakar Gas maka sejak bulan Mei tahun 2012 UD. Sandra beralih menjadi agen penyalur Gas LPG khususnya LPG 3kg dan berganti nama menjadi PT. Berkat Jabes sejak tahun 2013. Wilayah penyaluran Gas LPG 3Kg oleh PT. Berkat Jabes berlokasi di daerah Minahasa Selatan, antara lain Desa Kumelembuai, Desa Tokin, Desa Raanan Baru, Desa Motoling, Desa Wanga, Desa Ranoyapo, Desa Poopo, Desa Pontak, Desa Tompaso Baru, Desa Tumani, Desa Tambelang, Desa Linelean, Desa Pinasungkulan, Desa Makaaruyen, Desa Palelon.

Kantor administrasi yang mengurus kewajiban perpajakan PT Berkat Jabes berlokasi di kota Manado tepatnya di Jalan Sam Ratulangi 29 no. 1, kelurahan Tanjung Batu, lingkungan 4.

\section{Hasil Penelitian}

\section{Komponen Perpajakan dalam Harga Jual Eceran LPG 3 kg}

Berdasarkan Peraturan Presiden Republik Indonesia Nomor 104 Tahun 2007 Tentang Penyediaan, Pendistribusian Dan Penetapan Harga Liquefied Petroleum Gas Tabung 3 Kilogram, dalam rangka untuk menjamin penyediaan dan pengadaan Bahan Bakar di dalam negeri dan mengurangi subsidi Bahan Bakar Minyak guna meringankan beban keuangan negara, perlu dilakukan substitusi penggunaan Minyak Tanah ke Liquefied Petroleum Gas. Berdasarkan pertimbangan tersebut, perlu ditetapkan Peraturan Presiden tentang Pendistribusian, dan Penetapan Harga Liquefied Petroleum Gas Tabung 3 Kilogram.

Harga Jual eceran LPG $3 \mathrm{~kg}$ berbeda untuk setiap daerah. Khusus untuk daerah Manado, Pemerintah Daerah menetapkan harga jual terhadap agen dengan rincian sebagai berikut.

\section{Tabel 3. Rincian Harga Penebusan Refill/isi LPG 3Kg Pertamina}

\begin{tabular}{lc}
\hline $\begin{array}{l}\text { Harga pokok } \\
\text { PPN 10\% }\end{array}$ & Rp11.590,920 \\
& Rp1.159,092 a) \\
\hline HARGA PER TABUNG & $\mathbf{R p 1 2 . 7 5 0 , 0 1 2}^{\text {Rp }}$ \\
\hline PPH 0,3\% (dari harga pokok) & Rp12.773 $^{\text {b) }}$ \\
\hline HARGA PER TABUNG + PPH 0,3\% & Rp1.200 $^{\mathrm{c}}$ \\
\hline MARGIN AGEN (Rp400 x 3) & $\mathbf{R p 1 1 . 5 8 4 , 7 8 5}$ \\
\hline \multicolumn{1}{c}{ HARGA TEBUS DI PERTAMINA } \\
\hline
\end{tabular}

Sumber : PT Berkat Jabes 
a) PPN masukan sebagai dasar perhitungan SPT Massa PPN dan untuk pengkreditan pajak. Besarnya $10 \%$.

b) PPh Pasal 22 yang dipungut merupakan PPh Final karena PT. Berkat Jabes merupakan penyalur/agen resmi Pertamina. Tarif PPh 22 adalah sebesar 0,3\% untuk produk gas LPG.

${ }^{c}$ Untuk pembelian produk LPG $3 \mathrm{~kg}$ pemerintah menetapkan margin agen sebesar Rp1.200. Untuk ketentuan margin agen telah diatur dalam Peraturan Menteri Keuangan Republik Indonesia Nomor 64/Pmk.02/2012 Tentang Perubahan Atas Peraturan Menteri Keuangan Nomor 218/Pmk.02/2011 Tentang Tata Cara Penyediaan Anggaran, Penghitungan, Pembayaran, Dan Pertanggungjawaban Subsidi Liquefied Petroleum Gas (LPG) Tabung 3 Kilogram. Dalam pencatatan akuntansi/penjurnalan atas penebusan/pembelian LPG 3kg PT. Berkat Jabes mencatat Margin Agen (MA) sebagai pendapatan yang belum diterima perusahaan.

\section{Analisis Perhitungan PPh Pasal 22 dan PPN atas Penebusan LPG 3kg pada PT. Berkat Jabes}

Khusus untuk pembelian produk LPG 3kg dari PT Pertamina (Persero), PT. Berkat Jabes melakukan pembayaran ke bank persepsi menggunakan formulir setoran pembayaran produk pertamina yang disetor terdiri dari harga beli, PPN dan PPh Pasal 22. Kemudian formulir setoran tadi di bawa ke PT. Pertamina untuk ditukarkan dengan Surat Perintah Pengeluaran Barang (SPPB) yang diterbitkan oleh PT. Pertamina. Selanjutnya SPPB tadi berfungsi sebagai surat perintah kepada depot tersebut untuk mengangkut dan mengirimkan produk LPG $3 \mathrm{~kg}$ yang dibeli.

Adapun Jurnal atas transaksi Penebusan produk LPG 3kg oleh PT. Berkat Jabes adalah sebagai berikut.

a. Pada saat Pembelian

Uang muka Pembelian $\quad \mathrm{xxx}$

$$
\text { Bank } \quad x x x
$$

b.Pada saat Penerimaan Dokumen Pembelian

$\begin{array}{lll}\text { Pembelian } & \text { xxx } & \\ \text { PPN masukan } & \text { xxx } & \\ \text { Beban PPh pasal 22 } & \text { xxx } & \\ \quad \text { Margin agen } & & \text { xxx } \\ \text { Kas } & & \text { xxx }\end{array}$

Berikut penulis sajikan data untuk setiap transaksi penebusan/pembelian yang terjadi per bulan, mulai dari bulan Mei-Desember tahun 2012.

Tabel 4. Rekapan jumlah PPh Pasal 22 dan PPN yang dibayar per bulan atas penebusan refill/isi LPG $3 \mathrm{~kg}$ oleh PT. Berkat Jabes

\begin{tabular}{ccccc}
\hline NO & BULAN & HPP & $\begin{array}{c}\text { PPH 22 } \\
(\mathbf{0 , 3 \%} \mathbf{3 H P})\end{array}$ & $\begin{array}{c}\text { PPN } \\
(\mathbf{1 0 \%} \mathbf{x H P})\end{array}$ \\
\hline 1 & MEI & $\mathrm{Rp} 45.436 .406$ & $\mathrm{Rp} 136.311$ & $\mathrm{Rp} 4.543 .640$ \\
2 & JUNI & $\mathrm{Rp} 45.436 .406$ & $\mathrm{Rp} 136.311$ & $\mathrm{Rp} 4.543 .640$ \\
3 & JULI & $\mathrm{Rp} 97.363 .728$ & $\mathrm{Rp} 292.091$ & $\mathrm{Rp} 9.736 .372$ \\
4 & AGUSTUS & $\mathrm{Rp} 71.400 .067$ & $\mathrm{Rp} 214.200$ & $\mathrm{Rp} 7.140 .067$ \\
5 & SEPTEMBER & $\mathrm{Rp} 71.400 .067$ & $\mathrm{Rp} 214.200$ & $\mathrm{Rp} 7.140 .067$ \\
6 & OKTOBER & $\mathrm{Rp} 73.254 .614$ & $\mathrm{Rp} 219.764$ & $\mathrm{Rp} 7.325 .461$ \\
7 & NOVEMBER & $\mathrm{Rp} 82.063 .713$ & $\mathrm{Rp} 246.191$ & $\mathrm{Rp} 8.206 .371$ \\
8 & DESEMBER & $\mathrm{Rp} 110.345 .558$ & $\mathrm{Rp} 331.037$ & $\mathrm{Rp} 11.034 .555$ \\
\hline
\end{tabular}

Sumber: Dikelola penulis berdasarkan data formulir setoran pembayaran atas pembelian LPG $3 K g$ oleh PT. Berkat Jabes 


\section{Pembahasan}

Semua badan merupakan Wajib Pajak tanpa terkecuali, mulai saat didirikan atau saat melakukan kegiatan usaha atau memperoleh penghasilan. Tidak dipersoalkan apakah badan tersebut mengalami kerugian atau tidak memperoleh penghasilan sekalipun, tetap akan disebut sebagai Wajib Pajak (Christanty, Fita 2012).

\section{Analisis Perhitungan dan Pelaporan PPN pada PT Berkat Jabes}

(Mardiasmo, 2012 : 307) Undang-undang pajak PPN 1984 menganut metode kredit pajak (credit method) serta metode faktur pajak (invoice method). Dalam metode ini PPN dikenakan atas penyerahan BKP atau JKP oleh Pengusaha Kena Pajak. PPN dipungut secara bertingkat pada setiap jalur produksi dan distribusi. Unsur pengenaan pajak berganda atau pengenaan pajak atas pajak dapat dihindari dengan diterapkannya mekanisme pengkreditan pajak masukan (metode kredit pajak). Untuk melakukan pengkreditan pajak masukan, sarana yang digunakan adalah faktur pajak (metode faktur pajak).

Mekanisme pengenaan PPN dapat digambarkan sebagai berikut.

1. Pada saat membeli/memperoleh BKP/JKP, akan dipungut PPN oleh PKP penjual. Bagi pembeli, PPN yang dipungut oleh PKP penjual tersebut merupakan pembayaran pajak di muka dan disebut dengan Pajak Masukan. Pembeli berhak menerima bukti pemungutan berupa faktur pajak.

2. Pada saat menjual/menyerahkan BKP/JKP kepada pihak lain, wajib memungut PPN. Bagi penjual, PPN tersebut merupakan Pajak Keluaran. Sebagai bukti telah memungut PPN, PKP penjual wajib membuat faktur pajak.

3. Apabila dalam suatu masa pajak jumlah Pajak Keluaran lebih kecil daripada jumlah Pajak Masukan, selisihnya dapat diretribusi (diminta kembali) atau dikompensasikan ke masa pajak berikutnya.

4. Pelaporan penghitungan PPN dilakukan setiap masa pajak dengan menggunakan Surat Pemberitahuan Masa Pajak Pertambahan Nilai (SPT Masa PPN).

Dalam setiap transaksi pembelian/penebusan produk LPG 3kg yang dilakukan PT Berkat Jabes akan dipungut Pajak Pertambahan Nilai (PPN). PPN yang dipungut adalah sebesar 10\% dari hasil penjualan. Bagi PT. Berkat Jabes sebagai pembeli, PPN yang dipungut tersebut merupakan pembayaran pajak dimuka dan disebut dengan PPN Masukan. PPN Masukan tertinggi atas transaksi penebusan/pembelian refill/isi LPG 3kg yang dilakukan oleh PT Berkat Jabes terjadi pada bulan Desember 2012, dimana total pembelian tercatat sebesar Rp110.345.558 sehingga PPN yang dipungut adalah sebesar

$$
10 \% \mathrm{x} \operatorname{Rp} 110.345 .558=\mathrm{Rp} 11.034 .555
$$

Dan yang terendah terjadi pada bulan Mei dan Juni 2012 dimana total pembelian hanya sebesar Rp45.436.406. Sehingga PPN yang dipungut hanya sebesar

$$
10 \% \quad \mathrm{R} \quad \mathrm{Rp} 45.436 .406 \quad=\quad \mathrm{Rp} 4.543 .640 .
$$

Pelaporan harus dilakukan setiap bulan, paling lama akhir bulan berikutnya setelah berakhirnya Masa Pajak dan untuk setiap transaksi pembelian, PT Pertamina harus mengeluarkan faktur pajak PPN kepada PT Berkat Jabes.

\section{Analisis Perhitungan dan Pelaporan PPh Pasal 22}

Pajak Penghasilan Pasal 22 dalam rangka Penyerahan Barang atau Penjualan Hasil Produksi Pertamina berupa bahan bakar minyak, gas, dan pelumas dipungut/terutang pada saat penerbitan Surat Perintah Pengeluaran Barang (Delivery Order). Pemungutan PPh Pasal 22 atas penjualan/penyerahan barang atau penjualan hasil produksi Pertamina serta badan usaha lainnya yang bergerak di bidang bahan bakar minyak jenis premix, super TT dan gas dilaksanakan dengan cara penyetoran sendiri oleh agen/penyalur dalam hal ini PT. Berkat Jabes sebagai wajib pajak ke bank persepsi.

Penyetoran oleh PT. Berkat Jabes dilakukan 1 hari sebelum Surat Perintah Pengeluaran Barang (Delivery Order) ditebus. Penyetoran yang dilakukan oleh PT. Berkat Jabes sendiri sebagai agen/penyalur, tidak menggunakan Surat Setoran Pajak (SSP) tapi menggunakan Formulir Setoran Pembayaran Produk Pertamina.

Formulir Setoran Pembayaran Produk Pertamina tadi kemudian kita bawa ke PT Pertamina untuk ditukarkan dengan Surat Perintah Pengeluaran Barang (SPPB) yang diterbitkan oleh PT Pertamina. Selanjutnya SPPB tadi berfungsi sebagai surat perintah untuk mengangkut dan mengirimkan produk LPG $3 \mathrm{~kg}$ yang dibeli.

Pemungutan Pajak Penghasilan Pasal 22 atas penyerahan barang atau penjualan hasil produksi Pertamina serta badan usaha lainnya yang bergerak di bidang bahan bakar minyak jenis premix, super TT dan gas dengan tarif PPh 22 final 0,3\% dilaksanakan dengan cara penyetoran sendiri oleh Wajib Pajak ke bank persepsi atau Kantor Pos dan Giro sebelum Surat Perintah Pengeluaran Barang (delivery order) ditebus. Penyetoran pajak dilakukan secara kolektif dengan menggunakan formulir Surat Setoran Pajak. Pemungut pajak harus menyampaikan Surat Pemberitahuan Masa paling lambat 20 (dua puluh) hari setelah Masa Pajak berakhir. 
Berdasarkan data yang diperoleh dari PT Berkat Jabes, yaitu formulir setoran pembelian produk LPG $3 \mathrm{~kg}$ di bank persepsi pada bulan Mei-Desember 2012 dapat dilihat bahwa pembayaran PPh 22 yang tertinggi terjadi pada bulan Desember yaitu sebesar

$$
\operatorname{Rp} 110.287 .160 \times \quad 0,3 \% \quad=\quad \operatorname{Rp} 331.037
$$

Sedangkan pembayaran PPh 22 yang terendah terjadi pada bulan Mei dan Juni 2012 adalah sebesar

$$
\text { Rp45.436.406 } \quad \mathrm{x} \quad 0,3 \%=\operatorname{Rp} 136.311
$$

Karena bersifat Final, maka kewajiban Pajak untuk tahun 2012 dianggap lunas/ selesai, tetapi PT. Berkat Jabes masih tetap mempunyai kewajiban melaporkan SPT PPh Badan dengan perhitungan pajak terhutang disesuaikan dengan bukti pemotongan dari Pertamina dan sebagai pemungut Pertamina harus melaporkan SPT Masa PPh 22 ke Kantor Pelayanan Pajak paling lambat 20 hari setelah Masa Pajak berakhir dan menerbitkan Bukti Pemotongan PPh Pasal 223 rangkap.

\section{Kesimpulan}

\section{PENUTUP}

Berdasarkan hasil analisa dan pembahasan pada bab 4, maka kesimpulan yang dapat diambil adalah sebagai berikut.

1. Mekanisme penghitungan dan penyetoran PPh 22 yang terutang PT. Berkat Jabes selama periode bulan MeiDesember tahun 2012 telah sesuai dengan ketentuan PMK No. 224 Tahun 2012. PT. Berkat Jabes membayar $\mathrm{PPh}$ pasal 22 yang terutang pada saat penyetoran ke bank persepsi yaitu 1 hari sebelum Surat Perintah Pengeluaran Barang (Delivery Order) ditebus.

2. Dalam hal pelaporan PPh Pasal 22, karena bersifat Final, maka kewajiban Pajak untuk tahun 2012 dianggap lunas/ selesai, tetapi PT. Berkat Jabes masih tetap mempunyai kewajiban melaporkan PPh Pasal 22 dalam SPT PPh Badan sesuai jumlah pajak yang dipungut oleh Pertamina yang disesuaikan dengan bukti pungut yang ada.

3. Untuk perhitungan dan pembayaran PPN pun PT. Berkat Jabes telah membayar sesuai dengan jumlah pajak yang terutang, yang dibayar pada saat penyetoran ke bank persepsi.

\section{Saran}

Berdasarkan kesimpulan diatas, penulis dapat memberikan saran-saran yang mungkin dapat membantu PT Berkat Jabes dalam meningkatkan dan memperbaiki penerapan kewajiban perpajakannya yaitu sebagai berikut.

1. Sebagai agen/penyalur LPG 3Kg PT. Berkat Jabes memiliki kewajiban perpajakan yang harus dipenuhi, berhubungan dengan penelitian ini dalam hal pelaporan atas pembayaran PPh Ps 22 dan PPN atas penebusan LPG $3 \mathrm{Kg}$, PT. Berkat Jabes sebaiknya melengkapi dokumen-dokumen yang berhubungan dengan kewajiban perpajakan tersebut dan melakukan pencatatan akuntansi sesuai dengan transaksi penebusan/pembelian yang dilakukan perusahaan.

2. Perusahaan juga dapat mengikutsertakan karyawannya dalam pelatihan atau seminar perpajakan dan akuntansi agar perusahaan dapat melakukan pencatatan akuntansi yang tepat dan lebih memahami prosedur pelaporan pajak yang benar, mengingat adanya perubahan ketentuan dan peraturan perpajakan yang berlaku.

\section{DAFTAR PUSTAKA}

Christanty, Fita 2012. Analisis Ekualisasi Pajak Penghasilan Pasal 22 Dan Pajak Pertambahan Nilai Di PT. $K A S$.

Indriantoro, Supomo, 2012, Metode Penelitian Bisnis untuk Akuntansi dan Manajemen Edisi Pertama, BPFE Yogyakarta, Yogyakarta.

Muljono, Djoko, 2007, PPH dan PPN untuk Berbagai Kegiatan Usaha, Andi, Yogyakarta.

Mardiasmo, 2012, Perpajakan Edisi Revisi, Andi, Yogyakarta.

Peraturan Menteri Keuangan Republik Indonesia Nomor : 224/PMK.011/2012 Tentang Perubahan Atas Peraturan Menteri Keuangan Nomor 154/Pmk.03/2010 Tentang Pemungutan Pajak Penghasilan Pasal 22 Sehubungan Dengan Pembayaran Atas Penyerahan Barang Dan Kegiatan Di Bidang Impor Atau Kegiatan Usaha Di Bidang Lain. 
Peraturan Menteri Keuangan Republik Indonesia Nomor 64/Pmk.02/2012 Tentang Perubahan Atas Peraturan Menteri Keuangan Nomor 218/Pmk.02/2011 Tentang Tata Cara Penyediaan Anggaran, Penghitungan, Pembayaran, Dan Pertanggungjawaban Subsidi Liquefied Petroleum Gas (LPG) Tabung 3 Kilogram.

Peraturan Presiden Republik Indonesia Nomor 104 Tahun 2007 Tentang Penyediaan, Pendistribusian Dan Penetapan Harga Liquefied Petroleum Gas Tabung 3 Kilogram.

Rusdji, Muhamad 2007, Pajak Pertambahan Nilai dan Pajak Penjualan atas Barang Mewah, Gramedia, Jakarta. Sugiyono 2012, Metode Penelitian Kuantitatif, Kualitatif, dan R\&D edisi 16, Alfabeta, Bandung.

Undang-undang Nomor 42 Tahun 2009 Tentang Perubahan Ketiga UU PPN 1984. 